\title{
The Relationship Between Resources and Human Migration Patterns in Central Kamchatka During the Post-Soviet Period
}

\author{
Stephanie Hitztaler \\ University of Michigan
}

\begin{abstract}
This paper examines the relationship between resources and migration in post-Soviet Kamchatka (Russian Far East). During the post-Soviet period of socio-economic hardship, migration trends have changed drastically both in central Kamchatka and throughout the Russian Far East. I predicted that there would be a clear relationship between resource scarcity and people's decisions to leave in search of more propitious opportunities. Against the backdrop of economic decline, out-migration prevailed in central Kamchatka throughout the post-Soviet period; however, migration patterns among villages in this rural and resource-dependent region diverge considerably. Villages in central Kamchatka facing a local natural resource crisis show greater net negative migration than those with a relatively intact resource base. Such variation is notable, given the relatively contained area of the study; it suggests migration patterns are closely tied to ecological conditions. Besides socioeconomic and ecological factors, historical circumstances also influence migration patterns. The decision to migrate is complex, arising from the interaction of socioeconomic, political, ecological, and historical conditions.
\end{abstract}

KEY WORDS: natural resource scarcity; out-migration; population decline; central Kamchatka; post-Soviet period.

\section{INTRODUCTION}

Research on animal populations confirms that the resource levels are significant in shaping migration and dispersal patterns (e.g., Clarke \& Low,

Please address correspondence to Stephanie Hitztaler, School of Natural Resources, University of Michigan, Ann Arbor, MI 48109-1115. 
1992, p. 678). Specifically, times of resource abundance are correlated with in-migration; in contrast, out-migration is observed during periods of resource scarcity. Environmental extremes are not as constricting for humans as they are for other species (Low, 1989; quoted in Davis \& Daly, 1997 , p. 416). Nonetheless, humans across cultures should respond to resource levels in their migration patterns, with a general pattern of movement from areas of less to relatively greater opportunity. In a study of four parishes in 19th century Sweden, for instance, Low (1991, p. 428) observed an increased emigration rate in one parish during periods of bad harvests that led to a paucity of resources.

Besides ecological conditions, economic factors are a strong force in molding migration patterns. Empirical data from rural Ireland in the 19th and 20th centuries reveals that as relative wages and economic prospects decreased in Irish villages, out-migration rates began to rise (Strassmann \& Clarke, 1998, pp. 46, 48). By leaving the villages, people strove to better their economic situation, and in many cases to ensure future family formation as well.

In this paper, I examine the relationship of resources to migration patterns on the Kamchatka Peninsula in the Russian Far East during the post-Soviet period. In the central Kamchatka River valley, where my study site is based, the concurrent folding of the economic and ecological resource bases has drastically transformed former migration trends. This unique situation demonstrates how the interaction of socio-economic, political, ecological, and historical conditions affects people's migration decisions.

\section{History of Migration Patterns and Population Structure on Kamchatka}

Kamchatka's designation as a Far Northern Territory during the Soviet period has had important repercussions for both economic activity and migration patterns on the peninsula (Heleniak, 2001, p. 127). For instance, recruitment of labor to Kamchatka was hinged on salary incentives and other economic stimuli, such as greater accessibility to goods in deficit elsewhere in the Soviet Union. Such advantages were viewed as compensation to those willing to live and work in harsh ecological conditions. Consequently, people arrived on Kamchatka with the expectation of returning to "mainland" Russia after their stint of work, or upon retirement, with ample savings to obtain such luxuries as a car or apartment (Egorova, Koroleva, \& Talitskaya, 1993, p. 152).

The first wave of active settlement and expansion on Kamchatka began in the mid-1950s. A decade later, from the mid-1960s to the mid-1970s, a 
second, larger in-migration movement ensued thanks to an improved standard of living on Kamchatka. Migration patterns on Kamchatka generally mirrored those throughout the Russian Far East (RFE) where in-migration climaxed in the mid-1980s, but took a downward turn before the fall of the Soviet Union in 1992.

This high in-migration rate created one of youngest populations in the Soviet Union, with 66\%-70\% (Voinova, Zakharova, \& Rybakovsky, 1993, p. 17) in the prime working age group (25-44). Moreover, because it was considered prestigious to live and work in the RFE, and particularly on Kamchatka, immigrants were typically both highly educated and very mobile (Heleniak, 2001, p. 133), rendering their ties to the region tenuous.

Accordingly, there was a dearth of children, teenagers, and young people in the 15-25 age group (Murashko, Pika, \& Bogoyavlensky, 1993, p. 66); further, the proportion of people over 60 was negligible (Rybakovsky, 1990, p. 163). These patterns led to a demographic phenomenon in which population growth was primarily a product of migration instead of natural growth. In-migration ensured both steady growth and a constant contingent of young working age people in the overall population (Voinova et al., 1993, pp. 15-16).

In comparison to the distorted age structure of the immigrant population, that of Kamchatka's indigenous population had a normal triangular appearance, verifying the formation of this population through natural growth (Murashko et al., 1993, p. 66). The large numbers of young people and comparatively fewer people over 50 reflected the relatively high birth and death rates among this group.

\section{Post-Soviet Period}

The Soviet Union's dissolution in 1992 precipitated Kamchatka's slide into deep economic throes that were more keenly felt than elsewhere in Russia. The withdrawal of governmental subsidies, in tandem with price liberalization and the advent of market reforms, quickly dispelled all notions of prestige associated with the peninsula. Besides contending with rising inflation and the possibility of future unemployment, both common throughout Russia, Kamchatka residents were further burdened by problems in the shipment of goods and food products to the peninsula (Egorova et al., 1993, p. 145). As a result, the consumer basket cost in this region has been the most expensive in the country, pushing the subsistence level above the national average (Heleniak, 2001, pp. 147-148), and considerably lowering the former high standard of living. 
Economic turmoil coupled with great uncertainty concerning the future has catalyzed a striking reversal of former migration trends throughout the RFE, including Kamchatka. During the 1990s, population declined by $10 \%$ due almost exclusively to an outflow of people from this region (Heleniak, 2001, p. 139). The particularly low population stability of northern rural areas (Olenicheva, Motrich, Telushkine, \& Shkurkin 1992, p. 233), including my study site in central Kamchatka, has magnified this general trend.

The exodus consisted primarily of working-age people who fled to the Russian mainland due to its comparatively higher level of social infrastructure (Heleniak, 2001, p. 139). This trend was particularly apparent on Kamchatka, where potential migrants made up $30 \%$ of the population (Olenicheva et al., 1992, p.233). Despite their intentions, however, many simply did not have the financial or other resources to migrate (Heleniak, 2001, p. 147). This example of mass migration from a region with restricted resources and economic opportunities to one perceived as more plentiful is precisely aligned with ecological and economic theory. Below I outline hypotheses stemming from these theories and specify predictions relevant to my particular study site.

\section{HYPOTHESES AND PREDICTIONS}

When the resources in an area are vast, and individuals are able to gather plentiful amounts, we should see in-migration to this area. When resources become limited, the converse should be true. Economic conditions are closely tied to the state of the resource base. Because both economic and ecological resources are mandatory for family formation (for instance, marriage and reproduction), I make the following predictions:

(1) An outflow of people from all of the villages in my study site during the post-Soviet period should be observed as a consequence of the countrywide socio-economic crisis that has acutely affected rural dwellers in Russia's peripheral regions. Likewise, a decrease in the number of in-migrants should be recorded.

(2) Against the general backdrop of growing out-migration and shrinking in-migration numbers in the central Kamchatka River valley, I expect to find distinct variation in migration patterns among the populations in my study site. This variation stems from each village or region's ${ }^{1}$ differing socio-economic conditions and future prospects, which are influenced both by ecological and historical factors. Specifically, 
out-migration rates should be higher and in-migration rates lower in villages dependent wholly on logging activities. Moreover, overall higher out-migration and lower in-migration numbers should characterize recently founded, and thus less well-established, villages.

(3) Following the collapse of collectivized reindeer herding in the early 1990s, many indigenous peoples lost the last vestiges of their nomadic way of life; therefore, indigenous in-migration to the villages of Esso and Anavgai should increase during the post-Soviet period.

\section{DESCRIPTION OF KAMCHATKAN FORESTRY DISTRICTS AND VILLAGES}

Although distances of $70 \mathrm{~km}$ or less separate the villages in my central Kamchatkan study site, these villages nonetheless occur in distinctly different ecological landscapes with specific microclimates and physical features. They are also bound by different socio-economic and historical circumstances. Because the distinctions defining these villages are a crucial framework for my study, I elaborate upon them below.

\section{Ecological Characteristics}

With a harsh northern climate, Kamchatka has relatively low biodiversity; however, widespread volcanic activity on the peninsula has carved out diverse niches for plant, animal, and even human life here. This unique natural history helps explain the clear divergence in ecological conditions in central Kamchatka.

The communities in my study site are each located in a different forestry district (Figure 1). I used spatial analysis (remote sensing and geographical information systems (GIS)) to accomplish the following: objective quantification of physical resources; detection of large-scale resource use patterns; and measurement of human influence on the landscape. Analyses of land-cover and land-use patterns quantified diversity in the ecological landscape, and diversity in the level of human impact.

A comparison of land-cover maps for each district ${ }^{2}$ (Figures 2-4) reveals that fewer natural features constrain resource use in the Atlasovsky Forestry District (containing the village of Atlasovo) than in the Kozyrevsky or Bystrinsky Districts (containing the villages of Kozyrevsk, and Esso and Anavgai, respectively). A comparison of land cover in the Atlasovsky and Kozyrevsky Forestry Districts demonstrates that the physical features in the latter have somewhat curbed forest use. Specifically, more extensive logging has occurred in the Atlasovsky Forestry District than in the Kozyrevsky District (Table 1). 


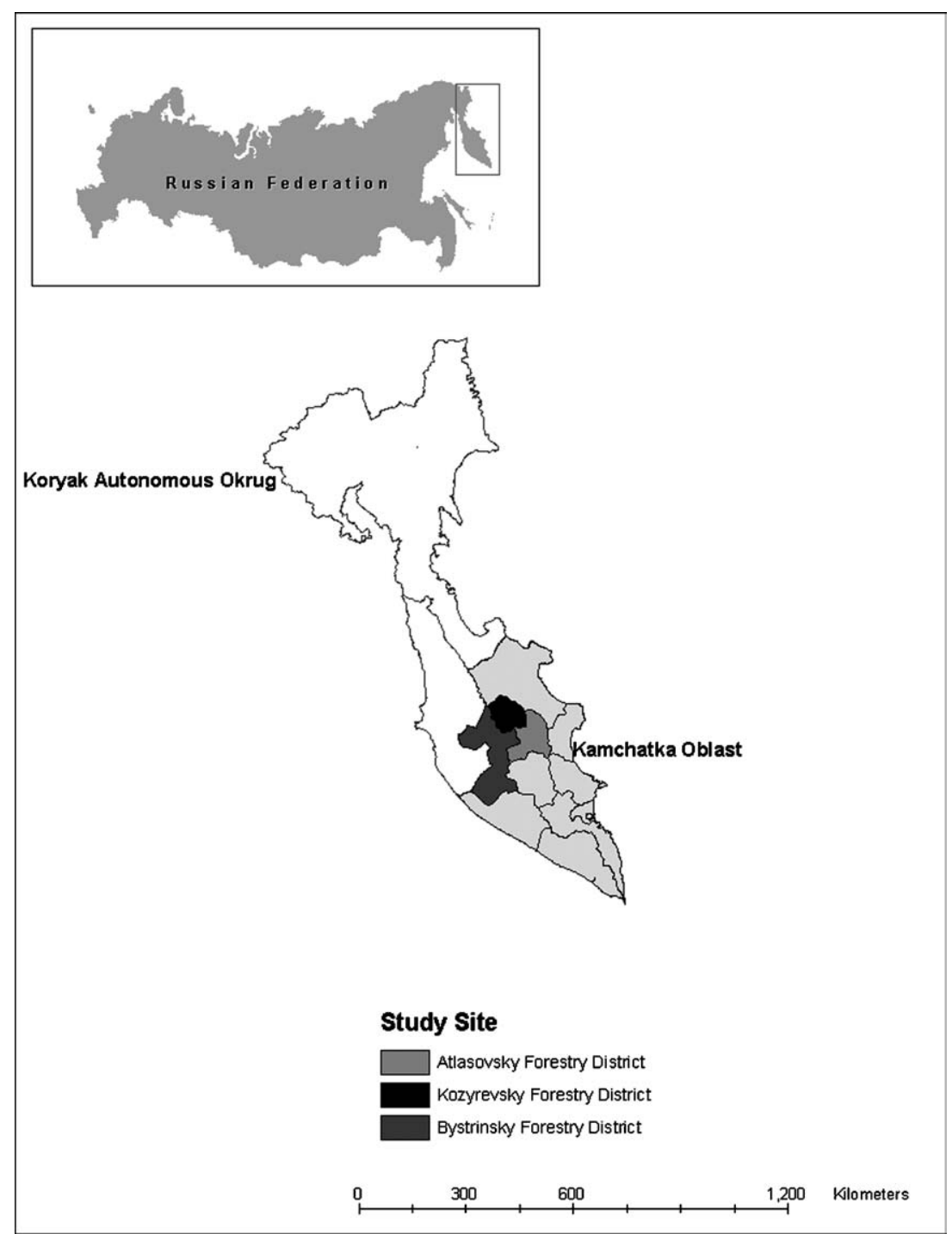

FIGURE 1. Study site in central Kamchatka. The villages of Atlasovo and Kozyrevsk, and the Bystrinsky Region, are located in the Atlasovsky, Kozyrevsky, and Bystrinsky Forestry Districts, respectively. 


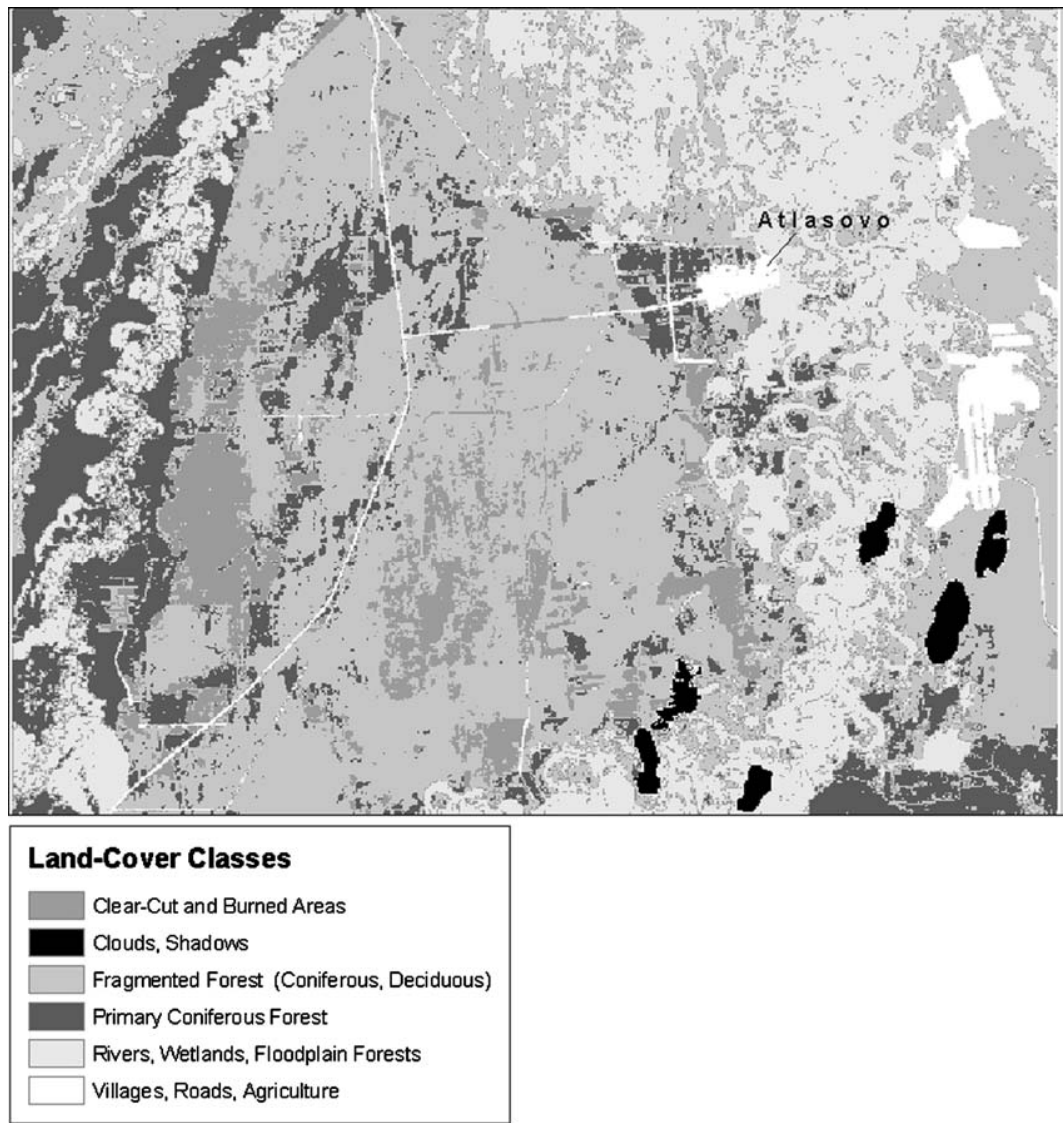

FIGURE 2. Land-cover map of the Atlasovsky Forestry District (scale: $27 \mathrm{~km} \times 36 \mathrm{~km}$ ). The coniferous forests on Kamchatka form the easternmost pocket of boreal forests; they consist primarily of larch (Larix kurilensis) and, to a lesser extent, spruce (Picea ajanensis). Forested land, and to a lesser extent, wetlands predominate the landscape in this district, located in the broadest and most arid section of the central Kamchatka River valley. With highly accessible forests, human impact has left an indelible mark in this district. Intensive, unsustainable logging spanning 40 years, coupled with fires, has resulted in a highly fragmented forest cover. This map reveals that the only significant stands of primary forest remain in the protected riparian zone along the Kozryevka River that runs near the left-hand edge of the map. Even though forests in this zone are officially protected, fresh gouges are evident, attesting to the scarcity of economically valuable timber in this region. 


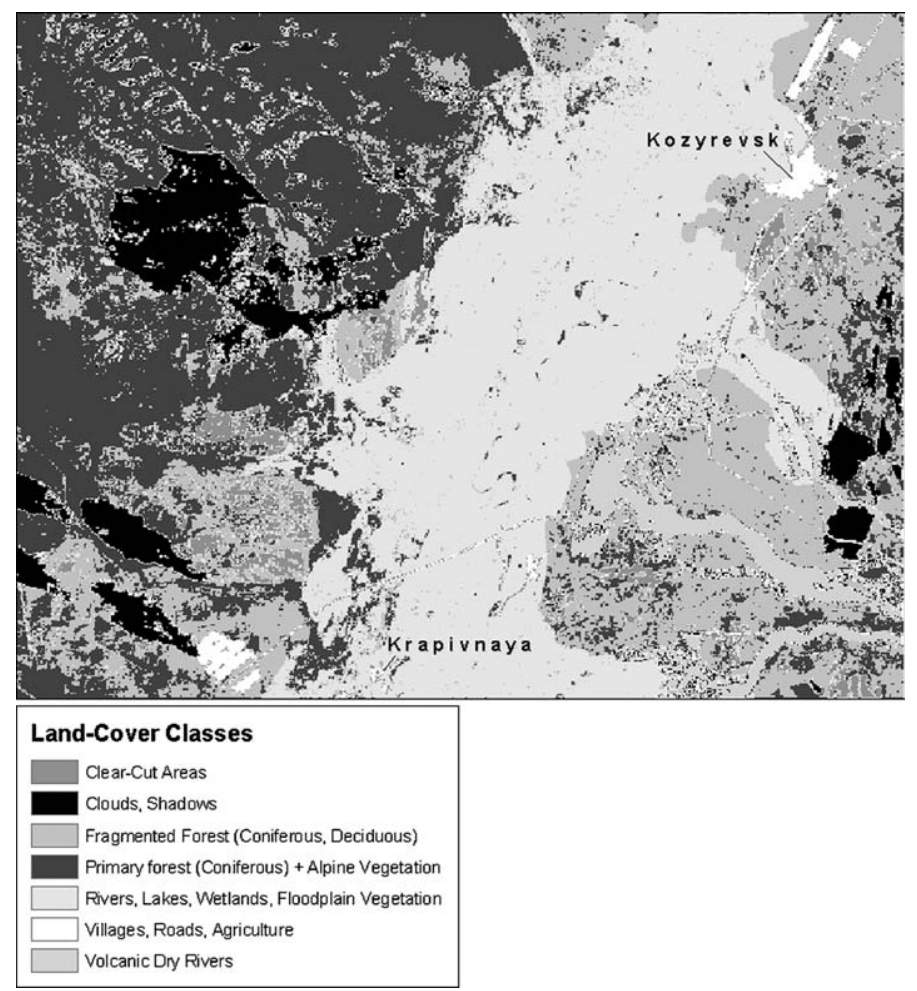

FIGURE 3. Land-cover map of the Kozyrevsky Forestry District (scale: $27 \mathrm{~km} \times 36 \mathrm{~km}$ ). Bordering the Atlasovsky Forestry District to the north, this district is situated in a narrower part of the Kamchatka River valley. Unlike the village of Atlasovo, the village of Kozyrevsk is bounded by wetlands and mountains to the west (shown in the light gray and dark gray vertical swaths in the center and left-hand side of the land-cover map, respectively), and a large volcanic massif further to the east (not pictured). Proximity to volcanic activity in this district has resulted in dry volcanic "rivers" (ash and debris) that punctuate a considerable portion of the forest landscape in this district (see the lower right-hand corner of the land-cover map). As in the Atlasovsky Forestry District, concentrated logging has occurred in this district, but to a lesser extent due in part to the physical constraints of the landscape, such as the volcanic dry rivers. In this map, the most expansive clear-cut areas occur in the lower-left hand corner of the map, northwest of the village, Krapivnaya. In this region, the valley begins to broaden, resulting in greater accessibility to forest resources. Krapivnaya was liquidated in the 1970 s due to the exhaustion of its forest resource base. Fire also occurs in this district, but is not as prominent as in the Atlasovsky Forestry District. 


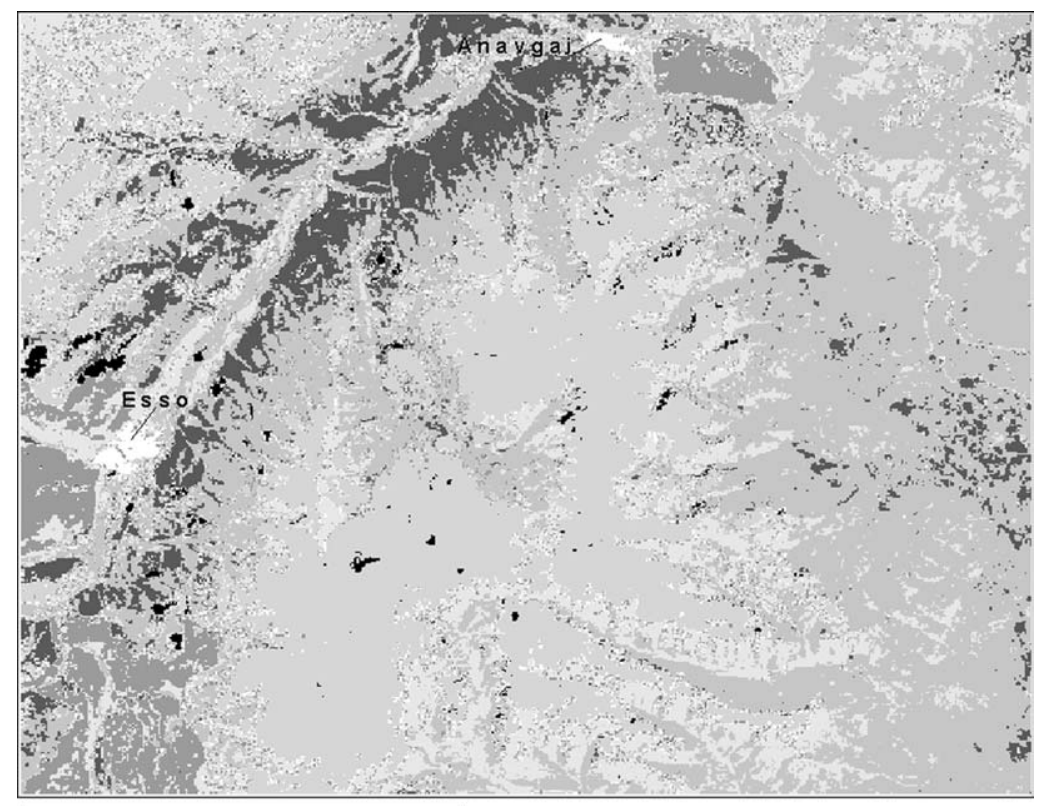

\begin{tabular}{|c|c|}
\hline \multicolumn{2}{|c|}{ Land-Cover Classes } \\
\hline & Alpine Vegetation, Rocky Outcrops \\
\hline & Burned Areas \\
\hline & I Clouds, Shadows \\
\hline & Deciduous, Mixed Coniferous/Deciduous \\
\hline & | Primary Forest (Larix kurilensis) \\
\hline & Rivers, Short Vegetation \\
\hline & Villages \\
\hline
\end{tabular}

FIGURE 4. Land-cover map of the Bystrinsky Forestry District (scale: $27 \mathrm{~km}$ $\times 36 \mathrm{~km}$ ). In contrast to the previous two forestry districts (figures 2 and 3), logging activity is not a prominent form of forest disturbance in the Bystrinsky Forestry District. Although systematic and intensive logging is present here, this activity is limited to the easternmost edge of this district that abuts the Kamchatka River valley to the west (not shown on this landcover map). The steep, mountainous relief in this district (center portion of map) has precluded the influx of large-scale logging operations as it simply is not cost-effective to cut and transport timber in this terrain with available equipment. Fire, however, is a major disturbance factor in this region, and typically occurs near settlements (see the medium-gray areas in the lower left-hand corner below the village of Esso, and to the right of the village, Anavgai). Although dry lightening is responsible for a few fires here, the majority of fires result from human carelessness. 
TABLE 1

Land Cover Types in the Study Region (in $\mathbf{k m}^{2}$ )

\begin{tabular}{lccc}
\hline & Atlasovsky & Kozyrevsky & Bystrinsky \\
\hline Primary Larch (Larix kurilnsis) Forest* & 87.90 & 85.41 & 92.30 \\
Fragmented Forest & 401.06 & 190.32 & - \\
Clear-Cut and Burned Areas & 69.99 & 26.93 & 39.87 \\
Volcanic Dry Rivers & - & 39.56 & - \\
Rocky Outcrops & - & - & 161.89 \\
\hline
\end{tabular}

Note that the Proportions of Both Forest and Clear-Cut/Burned Areas Differ across the Study Sites. *This land-cover type for the Atlasovsky and Kozyrevsky Forestry Districts does not appear on the maps modified for this paper; the figures presented in the table were calculated from the original land-cover maps with approximately twice the number of classes.

In addition, vector analyses performed in GIS sharpen the picture of land use and land cover provided by remotely sensed data. For instance, they elucidate the ties between resource accessibility and use. When GIS and remote sensing data are viewed together, it is evident that the most intensive forest use, and subsequent fragmentation, occurs in highly accessible areas that are typically characterized by a well-developed network of forest roads. This relationship is exemplified in the Atlasovsky Forestry District, and to a lesser extent, the Kozyrevsky District. The Atlasovsky Forestry District in particular has an extensive network of forest roads used in logging operations. In contrast, the comparative dearth of forest roads in the Bystrinsky district correlates with less intensive forest use (Figure 5).

\section{Economic Characteristics}

The local economic bases of each village also diverge considerably. In this rural area, villages have traditionally depended wholly on extractive activities (e.g., logging, fishing, hunting) as their economic lifeblood. Consequently, the relationship between natural and economic resources is readily apparent in this region, especially in comparison to large, complex cities. Thus, in addition to ecological differences, I expect that the socioeconomic and historical distinctions outlined below underlie corresponding variation in migration patterns among the villages in my study site.

Following the Soviet Union's dissolution, all villages in central Kamchatka faced grim economic prospects; however, some communities were struck harder than others. The village of Atlasovo, for instance, revolved around the Kamchatsky Forestry Enterprise (formerly, the largest on Kamchatka); thus, the collapse of this enterprise in the early 1990s drastically 


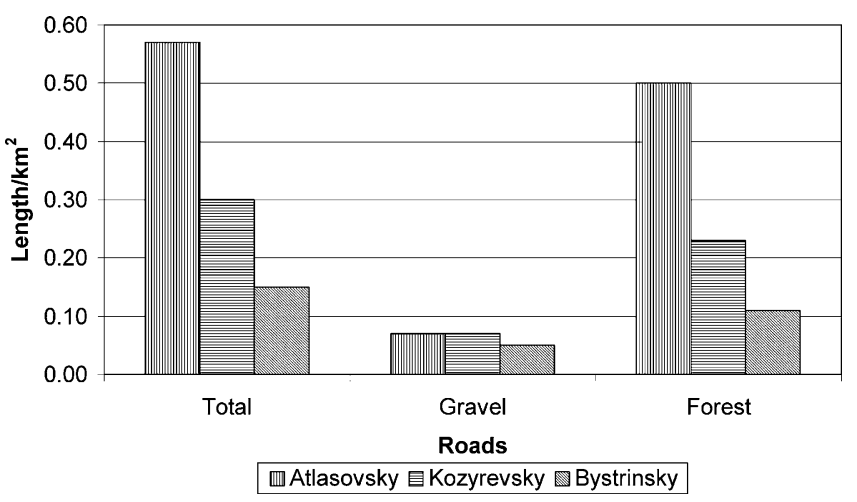

FIGURE 5. Comparison of transportation (road) networks among the three forestry districts. Road length is given relative to the total area of the district considered in this study. The areas for the Atlasovsky, Kozyrevsky, and Bystrinsky Districts are 2191.66, 2938.10, and $3101.22 \mathrm{~km}^{2}$, respectively.

curtailed economic activity in the village. Today, in the absence of other prospects, logging still forms the backbone of Atlasovo's economy. Yet considering the highly fragmented forest base in the Atlasovsky Forestry District, the future of forestry here appears tenuous at best.

The village of Kozyrevsk, like Atlasovo, was built to support logging operations in central Kamchatka. Consequently, it, too, was deeply affected by the onset of economic crisis in the early 1990s. The comparatively smaller forestry enterprise in Kozyrevsk, however, harvested less timber than that in Atlasovo. Additionally, as one of the oldest settlements in the central Kamchatka River valley, Kozyrevsk's historical roots run deeper than those in Atlasovo, granting it a greater sense of stability. Today, logging is still important to Kozyrevsk, but the economic base is beginning to diversify: a telecommunications company now runs a small office in the village, and tourism is quickly gaining momentum.

In contrast to Atlasovo and Kozyrevsk, the share of forestry in the local economies of Esso and Anavgai villages in the Bystrinsky Region is minor. In fact, no particular extractive activity serves as the lifeline for this region. Esso, the regional capital, is an administrative center, with many specialists working in the social, financial, and organizational spheres. The mountainous location of these two villages has proven particularly propitious, especially considering the abundant geothermal water source that provides the region with a continuous, cost-effective supply of heat. This resource, in conjunction with plentiful electricity provided by a newly built hydroelectric 
station in this region, has greatly boosted the village's prospects for emerging from its post-Soviet economic slump. Moreover, this region's picturesque surroundings have made it a prime candidate for the development of tourism.

\section{MATERIALS AND METHODS}

\section{The Sample and Data Analyses}

The sample for this study consists of populations from Atlasovo, Kozyrevsk, Esso, and Anavgai during the post-Soviet period, specifically 1991-2001. The data contain aggregate numbers for each village; there are no data for individuals. This study is centered on the analysis of in-, out-, and net migration for these villages.

\section{Variation in Village Samples}

I collected demographic data during the summers of 2001 and 2002. Although my study overlapped with the 2002 nationwide census in Russia, I was not able to obtain the new census data in time to incorporate them into this study. Data used in this study came primarily from the Kamchatka Oblast (a political division similar to a U.S. state) Committee of Governmental Statistics in Petropavlovsk-Kamchatsky, the capital of Kamchatka. I also accessed data from administrative departments in Esso, including the Bystrinsky Department of Statistics. Because data were typically available on a fee-only basis, I was limited in the quantity I could acquire. Moreover, despite my best attempts to ensure consistency, some discrepancies in the data were simply unavoidable. For instance, migration data were available for Atlasovo only until 1996; after this year they were aggregated with data from other villages in the region.

\section{RESULTS AND DISCUSSION}

In the analyses that follow, I present in-, out-, and net migration numbers for the villages in my study site. Note, however, that these data do not reveal the full story of migration patterns. For instance, they do not indicate the numbers of those who wished to leave but could not due to financial and other constraints. Towner (1999, p. 93) corroborated in her model of human dispersal that the poorest sectors of the population frequently simply did not have the option to leave, even though it might have been in their best interest. 
In the discussion, I explicate the observed variation among the villages by teasing apart the specific, intertwined factors, such as ecological and historical setting, and socio-economic conditions, that affect migration. To address the question of exactly why people leave, I use a survey conducted among Kamchatka residents in 1992. I interpret these survey responses in light of this paper's main premise that resource levels are closely connected to people's decision to remain in an area or to leave.

\section{In-, Out-, and Net Migration Numbers}

Migration numbers throughout my study site conform to the overall patterns of increased out-migration and decreased in-migration observed throughout Kamchatka during the post-Soviet period. Nonetheless, comparisons of each locality reveal distinct variation in migration patterns.

First, in-migration patterns for Atlasovo and Kozyrevsk are roughly parallel from 1991 to 1996 (Figure 6). For example, the inflow of people to Atlasovo equaled 25, 26, 41, and 27 in 1993, 1994, 1995, and 1996, respectively, compared to the arrival of 31, 18, 50, and 31 for the same years in Kozyrevsk. The number of in-migrants, however, differed greatly between Kozyrevsk and the Bystrinsky Region ${ }^{3}$ from 1998 to 2000. Specifically, 117 people moved into the Bystrinsky Region in the year 2000, whereas only four people relocated to Kozyrevsk.

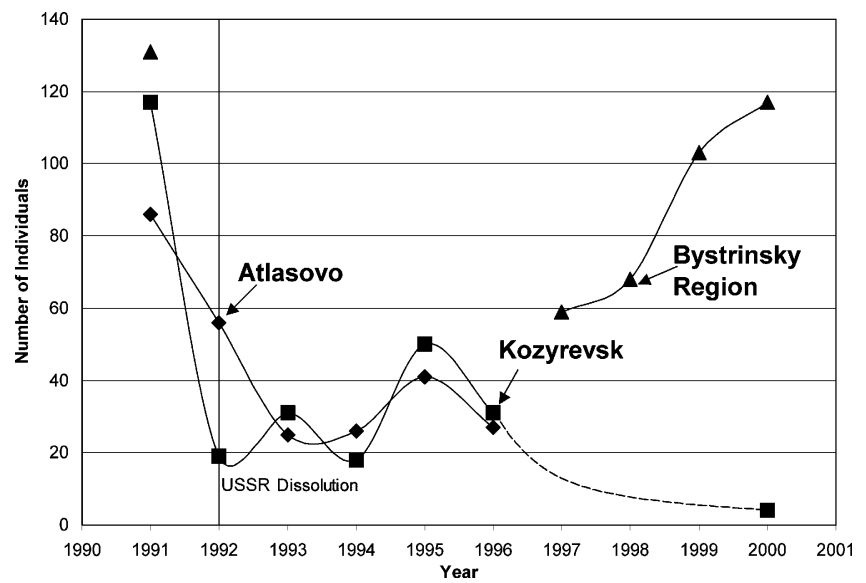

FIGURE 6. In-migration numbers in Atlasovo, Kozyrevsk, and the Bystrinsky Region, 1991-2001. (The dashed line indicates missing data.) 
Second, in contrast to in-migration trends for Atlasovo and Kozyrevsk, out-migration numbers for the two villages diverge considerably, particularly during the period 1992-1994 (Figure 7). Atlasovo lost 168, 129, and 156 people in 1992, 1993, and 1994, respectively; Kozyrevsk lost 48, 75, and 78 during the same years. Atlasovo's losses are especially pronounced given its smaller population base. ${ }^{4}$ Out-migration numbers for the Bystrinsky Region appear to be fairly stable during this period. From 1998 to 2001, they showed little fluctuation, ranging from 80 to 91 .

Third, net migration for each village or region is juxtaposed in Figure 8. In Atlasovo, net migration was lowest in the years 1992 and 1994, dropping to -112 and -130 individuals, respectively. Although still negative, net migration began to stabilize somewhat in 1995 and 1996 at -44 and -33 individuals, respectively.

It appears that people did not flee as quickly from Kozyrevsk as they did from Atlasovo: net migration in the former hit low points in 1994 and 1996 at -60 and -53 individuals, respectively. Following the 1994 low, net change rose to -22 individuals. The low points in 1994 for both villages reflect an overall trend in the RFE: 1994 was a peak year for net migration loss throughout the Russian Far East (Heleniak, 2001, p. 139).

After a presumed drop from 1991, data for the Bystrinsky Region from 1997 to 2001 show steadily climbing net migration numbers that become positive in 1999 and 2000. Overall, it is evident that the Bystrinsky Region

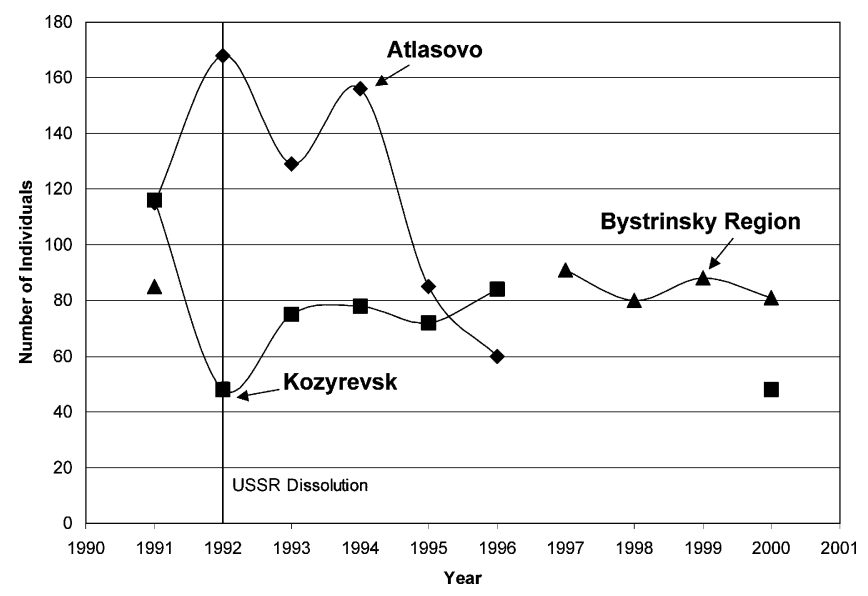

FIGURE 7. Out-migration numbers in Atlasovo, Kozyrevsk, and the Bystrinsky Region, 1991-2001. 


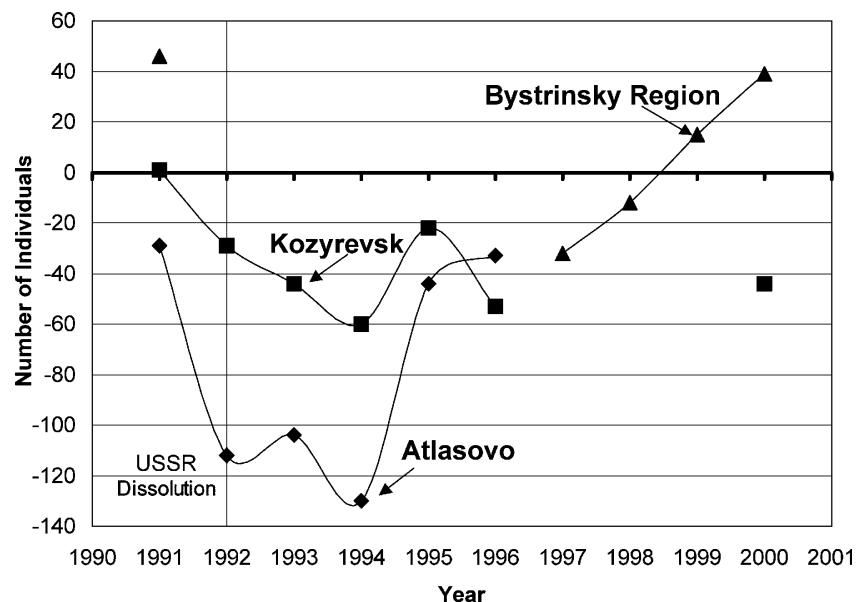

FIGURE 8. Comparison of net migration numbers in Atlasovo, Kozyrevsk, and the Bystrinsky Region, 1991-2000.

has lost relatively fewer people due to migration than Kozyrevsk and, in particular, Atlasovo where the greatest outflow of people has occurred.

Finally, although data are missing on indigenous migration, other sources relate that out-migration among this group was very low. For instance, only $4 \%$ of the indigenous population emigrated in 1992 (Egorova et al., 1993, p. 143). Movement of this population within the region, however, is apparent. In both the villages of Esso and Anavgai, the number of permanent indigenous residents has been on the rise during the postSoviet period.

\section{Migration Variation in Time and Space}

In- and out-migration patterns in central Kamchatka have reversed, resulting in net out-migration. According to Lee (1990, p. 1), "migration is a significant factor in the way demographics respond to economic crisis." It is apparent that the ubiquitous negative net migration numbers in central Kamchatka are a direct outcome of the post-Soviet economic crisis. In this region, crisis conditions permeated life so deeply that one local administrator commented: "This period [early to mid-1990s] was the most difficult. We did not know if we would live through this time."

Although immense economic hardship is no doubt at the core of current migration patterns in central Kamchatka, it is more difficult to pinpoint an explanation for the observed variation ${ }^{5}$ among populations in central 
Kamchatka. Here I explore how interwoven factors, such as ecological and socio-economic conditions, and historical setting, give rise to area-specific variation in migration patterns. In an effort to sort through these complex relationships, I examine each village separately, and then draw comparisons among them. Finally, I briefly discuss the unique situation of indigenous peoples in the Bystrinsky Region.

In Atlasovo, the mass departure of people in the early 1990s coincided precisely with the 1993 liquidation of the Kamchatsky Forestry Enterprise. Although this enterprise was formerly one of the leading timber producers in the Soviet Union, it nonetheless joined the ranks of many other operations on Kamchatka that could neither remain solvent nor compete in the new market conditions of the 1990s.

Its plight, however, was intensified by a crisis in the forestry sector that coincided with the larger socio-economic crisis: severe degradation of the timber base (Khomentovsky, 1999). Unlike other regions in Russia with vast forest expanses, logging activities on Kamchatka are confined to the Kamchatka River valley that fosters the only significant growth of coniferous forests on the peninsula.

So thoroughly was the Kamchatksy Forestry Enterprise integrated into village life that its bankruptcy catalyzed striking changes in population agestructure. Impoverished, many people were stranded in Atlasovo, including people of or nearing retirement age. The current head of Atlasovo's administration spoke of this phenomenon, contrasting it with the virtual absence of retired people during Atlasovo's boom years. ${ }^{6}$

Atlasovo experienced a slight recovery when, although they were still negative, net migration numbers began to ascend in 1995 and 1996. This trend most likely reflects the emergence of small, privatized logging firms in the absence of the former giant state forestry enterprise. These firms have helped curb the unemployment rate in Atlasovo.

In Kozyrevsk, the greatest population loss appears to have coincided with the events leading to Russia's 1998 financial crisis and the subsequent spike in inflation, as well as with the record low timber production registered by the Kozyrevsky Forestry Enterprise in 1999. Although the concurrent socio-economic and natural resource crises in the Kamchatka River valley reduced the enterprise's timber production to a fraction of its former volume, it has continued to operate throughout the post-Soviet period, unlike the enterprise in Atlasovo.

The divergent fate of these enterprises may likely be traced to varying resource levels in the Atlasovsky and Kozyrevsky Forestry Districts. Despite the centrality of forestry in the local economies of Atlasovo and Kozyrevsk, spatial analyses confirm less systematic forest exploitation in the Kozyrevsky 
Forestry District than in the Atlasovsky District (see Figures 2 and 3). Besides greater accessibility to forests in the latter district, its network of forest roads is much more extensive (Figure 5). Moreover, the village of Atlasovo was strategically located near a main thoroughfare that facilitated land transportation of timber to southern ports in Petropavlovsk-Kamchatsky.

Conversely, the Kamchatka River has posed a formidable barrier to land transport of timber from Kozyrevsk, situated on the east bank of the river. To reach the main road to Petropavlovsk-Kamchatsky, timber had to be ferried across the river, ${ }^{7}$ a major impediment. An unfavorable road connection to the north of Kozyrevsk further hindered the land transportation of timber. Both obstacles resulted in higher shipping costs.

Because Kozyrevsk's forestry enterprise persisted, mass unemployment in this village was less evident than in Atlasovo as the comparatively gradual fall in net migration numbers corroborate. These numbers also reflect more favorable conditions in Kozyrevsk. The start-up of a telecommunications branch office may explain the spike in these numbers in 1995. Alternately, it could be a reflection of resettlement by former villagers. Accounts of nostalgic families returning to Kozyrevsk are fairly common in village circles.

A comparison of these two villages suggests a strong tie between history and migration patterns. Stable, well-established communities seem to have checked mass out-migration during the post-Soviet period. Recognized as an anchor settlement in the central Kamchatka River valley, Kozyrevsk has drawn people back after their initial decision to leave. In contrast, Atlasovo's high out-migration numbers seem to mirror the village's transience. Here migration patterns appear as a product of current and past conditions.

Data discrepancies make it more difficult to analyze the situation in the Bystrinsky Region. Nonetheless, available data reflect comparatively moderate net migration changes in this region. It is possible that this region's relatively broader economic base has helped safeguard the population from severe fluctuations (see Low \& Clarke, 1993, p. 214). A bountiful source of geothermal heat, an inexpensive nearby source of hydropower, and an association as the "Switzerland of Kamchatka," have made this region an attractive place to live.

The Bystrinsky Region, however, has not been impervious to economic hardships: net population change slid greatly from 1990 to 1993 and was negative until 1997 (Hitztaler, 2003). Yet, economic recovery appears hopeful here, especially with fledgling tourism prospects and the recent creation of a nature park. ${ }^{8} \mathrm{~A}$ regional administrator confirmed the growing 
desirability of the region, and Esso in particular, by pointing out the village's few vacant homes.

Finally, in comparison to non-indigenous peoples (primarily ethnic Russians and Ukrainians), indigenous people in the Bystrinsky region have fared particularly poorly during the post-Soviet period (Egorova et al., 1993, p. 148). The economic base for many indigenous peoples abruptly collapsed when the government slashed subsidies for reindeer herding collectives. The ensuing mass unemployment among these peoples precipitated a shift to permanent residence in Esso and Anavgai (Hitztaler, 2004). ${ }^{9}$ Yet, there seems to be a weak link, if any, between greatly constricted resources and migration patterns among this group. Economically and socially marginalized, ${ }^{10}$ these people most likely do not have the material means to migrate. Equally important, unlike the majority of the non-indigenous population here, many indigenous peoples may not have the desire to uproot from their traditional territory.

\section{Why People Leave}

In surveys conducted in 1987 and 1992 on Kamchatka (Egorova et al., 1993, pp. 146, 147), respondents cited poor material conditions (e.g., low food supply) as a primary reason for leaving. Other reasons included harsh climate and health problems, both connected to lowquality food, poor working conditions, and poor medical service. Worsening circumstances on Kamchatka during the post-Soviet period is pithily captured in responses to the following question: "How does the present and past (5-10 years ago) standard of living on Kamchatka compare with that in other regions of Russia?" Two-thirds of the respondents replied that salaries 5-10 years ago were higher on Kamchatka than elsewhere in Russia; they also answered that availability of goods, food products, and housing, was greater on Kamchatka. Four-fifths answered that current salaries on Kamchatka had shrunk to levels much lower than in other regions.

This survey is illuminating: a dearth of the most basic resources, for example, food and adequate housing, clearly underlie out-migration from Kamchatka. This survey also explicates the large influx of settlers to Kamchatka between the late 1950s and 1970s; they risked the journey to secure higher salaries, better housing, and larger quantities of food and goods. These answers are completely congruent with the ecological hypothesis that constricted resources spur out-migration and vice versa. Rational actor theory from economics is also relevant. Both underscore the centrality of resources to migration patterns. 


\section{CONCLUSION}

Similar to previous studies (e.g., Low and Clarke, 1992), this paper underscores the connection between resources and migration. This relationship is especially linear in the RFE in general and on Kamchatka in particular, both before and after the official dissolution of the Soviet Union in 1992. Each time period is discrete, marked by an abundance or paucity of resources. People have responded to these situations in their migration decisions, leaving less favorable areas in search of better opportunities to secure resources for their immediate well-being, and for long-term family prospects.

Migration patterns in central Kamchatka reflect broader patterns throughout the RFE and Kamchatka. In the small villages that dot the central Kamchatka River valley, people frequently mention the dying out of their communities. Although not everyone shares this gloomy outlook, the signs of recent population loss are unmistakable: boarded up windows, deserted clubhouses, and eerily silent timber yards all attest to the great transformation these villages have undergone in a relatively short time span.

On a finer scale, the data presented in this paper tell of dynamic migration patterns that fluctuate in response to local conditions. I have attempted to tease apart the interrelated factors - such as ecological, socioeconomic, and historical conditions - that cause local variation in migration patterns. In rural central Kamchatka, the connection between local resource base, socio-economic conditions, and migration patterns is particularly pronounced: communities facing local resource crises, particularly Atlasovo and, to a lesser extent, Kozyrevsk show greater net negative migration than the Bystrinsky region, an area with a relatively intact resource base. Such variation amid a nationwide economic crisis is remarkable, especially within a relatively small and contained area.

\section{ENDNOTES}

1. In this study, two similar villages in proximity to one another within the same administrative region are collectively referred to as the Bystrinsky region as it was not possible to get separate data for each village. (These are the only two official settlements occurring within this region).

2. It was beyond the scope of this study to analyze the entire area of a district; however, the portions of these districts that appear in this study should be representative.

3. No migration data were available for Atlasovo during this period.

4. Kozyrevsk's overall population numbers for the years 1990, 1994, 1996, and 1998 were 2298, 2205, 2200, and 2013, respectively; Altsovo's population numbers for these same years were 1490,1090, 1030, and 1010, respectively. 
5. Similar variation occurred in the fertility patterns in this area (Hitztaler, this issue).

6. This period lasted roughly 25 years, from the early 1960s to mid-1980s. During this period, people typically returned to their place of origin upon reaching retirement age.

7. Due to the constantly changing course of the Kamchatka River, it is not feasible to build bridges across it.

8. In Russia, a nature park is a type of protected area that is similar to a national park with the exception that it is administered on a regional, as opposed to national, level.

9. Widespread unemployment is also vividly illustrated in fertility patterns among this population (Hitztaler, this issue).

10. Even within the small village of Esso (population ca. 2100 people), there is an area designated as an indigenous "quarter" where the majority of the indigenous population lives.

\section{REFERENCES}

Clarke, A. L., \& Low, B. (1992). Ecological correlates of human dispersal in 19th century Sweden. Animal Behavior, 44, 677-693.

Davis, J. N., \& Daly, M. (1997). Evolutionary theory and the human family. The Quarterly Review of Biology, 72(4), 407-435.

Egorova, O. P., Koroleva, G., \& Talitskaya, T. (1993). Sovermenniye tendentsii migratsii naseleniya Kamchatki. In L. Rybakovsky (Ed.), Sotsial'no-demograficheskoe razvitie Rossiiskogo severa. Moscow: Rossiiskaya Akademiya Nauk, Institute Sotsial'no-Ekonomicheskikh Problem Narodonaseleniya.

Hitztaler, S. H. (2004). Transformations in post-Soviet Kamchatka: The relationship between resources and changing human population patterns. Master's Thesis, School of Natural Resources and Environment, Center for Russian and East European Studies, University of Michigan.

Heleniak, T. (2001). Demographic change in the Russian Far East. In M. Bradshaw (Ed.), The Russian Far East and Pacific Asia: Unfulfilled potential. Richmond, Surrey, U.K.: Curzon Press.

Khomentovsky, P. A. (1999). Sokhranenie lesov Kamchatki. Petropavlosk-Kamchatsky, Kamchatka: Goskomkamchatekologiya.

Lee, R. (1990). The demographic response to economic crisis in historical and contemporary populations. Population Bulletin of the United Nations 29, 1-15.

Low, B. S., (1989). Human responses to environmental extremeness and uncertainty: A crosscultural perspective. In E. Cashdan, (Ed.) Risk and Uncertainty in Tribal and Peasant Economies (pp. 229-255). Westview Press, Boulder, CO.

Low, B. S. (1991). Reproductive life in 19th century Sweden: An evolutionary perspective on demographic phenomena. Ethology and Sociobiology, 12, 411-468.

Low, B. S., \& Clarke, A. (1992). Resources and the life course: Patterns through the demographic transition. Ethology and Sociobiology, 13, 463-494.

Low, B. S., \& Clarke, A. (1993). Resource control, fertility, and migration. In G. Ness, W. Drake, \&S.Brechen (Eds.), Population-Environment Dynamics: Ideas and Observations. Ann Arbor, MI: University of Michigan Press.

Murashko, O. A., Pika, A., \& Bogoyavlensky, D. (1993). Sotsial'no demograficheskie protsessy na krainem severe-Alaska i Rossiisky Dal'nii Vostok: Sravnitel'noe issledovanie, sotsial'no-demograficheskie transformatsii na Kamchatke, II.

Olenicheva, M. R., Motrich, E., Telushkina, E., \& Shkurkin, A. (1992). Soviet Far East: problems of demography and labor resources. Scientific Life, 3(3), 232-236.

Russia, Goskomstat-Kamchatsky Oblastnoi Komitet Gosudarstvennoi Statistiki. (2001). Migratsiya naseleniya Kamchatskoi oblasti za 2000 god. 
Rybakovsky, L. L. (1990). Naselenie Dal'nego Vostoka za 150 let. Moscow, Akademiya Nauk USSR, Institute Sotsiologii.

Strassmann, B. I., \& Clarke, A. (1998). Ecological constraints on marriage in rural Ireland. Evolution and Human Behavior, 13, 33-55.

Towner, M. C. (1999). A dynamic model of human dispersal in a land-based economy. Behavioral Ecology and Sociobiology, 46, 82-94.

Voinova, V. D., Zakharova, O., \& Rybakovsky, L. (1993). Sovremennyi rossiiskii sever i ego naselenie. In L. Rybakovsky (Ed.), Sotsial'no-demograficheskoe razvitie Rossiiskogo severa. Moscow: Rossiiskaya Akademiya Nauk, Institute Sotsial'no-Ekonomicheskikh Problem Narodonaseleniya. 